\title{
Metabolic syndrome in children born small-for-gestational age
}

\author{
Síndrome metabólica em crianças nascidas \\ pequenas para a idade gestacional
}

María Isabel Hernández', Verónica Mericq'

\section{SUMMARY}

Being born small-for-gestational age and a rapid increase in weight during early childhood and infancy has been strongly linked with chronic diseases, including metabolic syndrome, which has been related to intrauterine life environment and linked to epigenetic fetal programming. Metabolic syndrome includes waist circumference $\geq 90^{\text {th }}$ percentile for age, sex and race, higher levels of blood pressure, triglycerides and fasting glucose, and low levels of HDL-cholesterol. Insulin resistance may be present as early as 1 year of age, and obesity and/or type 2 diabetes are more prevalent in those born SGA than those born AGA. The programming of adaptive responses in children born SGA includes an association with increased blood pressure, changes in endothelial function, arterial properties and coronary disease. Early interventions should be directed to appropriate maternal nutrition, before and during pregnancy, promotion of breast feeding, and prevention of rapid weight gain during infancy, and to promote a healthy lifestyle. Arq Bras Endocrinol Metab. 2011;55(8):583-9

\section{Keywords}

Small-for-gestational age; metabolic syndrome; waist circumference

\section{SUMÁRIO}

Crianças nascidas pequenas para a idade gestacional (PIG) e um rápido ganho de peso durante a primeira e segunda infâncias estão fortemente ligados à ocorrência de doenças crônicas, incluindo a síndrome metabólica, o que está relacionado ao ambiente intrauterino e a alterações epigenéticas da programação fetal. A síndrome metabólica envolve uma circunferência abdominal $\geq$ ao percentil 90 para a idade, sexo e raça, níveis mais altos de pressão sanguínea, triglicérides e glicose em jejum, e níveis baixos de HDL-colesterol. A resistência à insulina pode estar presente já no primeiro ano de vida, e a obesidade e/ou o diabetes tipo 2 são mais prevalentes em crianças nascidas PIG do que naquelas nascidas AIG. A programação de respostas adaptativas em crianças nascidas PIG inclui uma associação com uma pressão sanguínea mais alta, alterações na função endotelial e propriedades arteriais, e doença coronariana. Intervenções precoces devem ser direcionadas à nutrição apropriada, antes e durante a gravidez, promoção da amamentação e prevenção de ganho rápido de peso durante a infância e promoção de um estilo de vida saudável. Arq Bras Endocrinol Metab. 2011;55(8):583-9

Descritores

Pequeno para idade gestacional; síndrome metabólica; circunferência abdominal

\section{INTRODUCTION}

$\mathrm{B}$ eing born small-for-gestational age and a rapid increase in weight during early childhood and infancy has been strongly linked to a number of long-term risks including glucose intolerance (1), insulin resistance, type 2 diabetes $(2,3)$, higher systolic blood pressure (4), coronary heart disease (5), cardiovascular mortal-
${ }^{1}$ Institute of Maternal and Child Disease (IDIMI), School of Medicine, University of Chile, Chile

\author{
Correspondence to: \\ Verónica Mericq \\ Santa Rosa, 1234, second floor IDIMI \\ Casilla 226-3 - Santiago, Chile \\ vmericq@med.uchile.cl
}

Received on 5/Oct/2011 Accepted on 16/Oct/2011 ity $(6,7)$, elevated plasma cortisol (8), premature adrenarche and ovarian hyperandrogenism $(9,10)$. Those related diseases were initially observed retrospectively in an adult population by Barker and cols., but have been replicated in prepubertal and early pubertal children in longitudinal follow-up (11-13).

These observations led to the so-called Barker Hypothesis, "early origins of late diseases", which pointed 
to the intrauterine life environment as the main determinant of these conditions. Since this hypothesis, research has highlighted the link between epigenetics in fetal programming and the susceptibility to chronic disease (14), and the importance of the contribution of early weight gain has also been recognized. Size at birth, either small (SGA) or large (LGA) determines higher risk of developing chronic diseases. The common characteristic of these two types of babies is their higher adiposity. Apparently, those born LGA have this higher adiposity from intrauterine life, whereas those born SGA develop this condition after being born (15).

Thus, early interventions should be directed to appropriate maternal nutrition before and during pregnancy, promotion of breastfeeding and prevention of rapid weight gain during infancy, and to promote a healthy life style.

In this report, we will review the definitions of low birth weight and small-for-gestational age, metabolic syndrome, the epigenetic association, metabolic consequences and prevention.

\section{DEFINITIONS}

There is controversy in the definition of small-for-gestational age, because some issues have to be addressed according to the consensus statement published in 2007 (16). 1) Accurate knowledge of gestational age; 2) Accurate measurement of weight, length and head circumference at birth; and 3) A cutoff value based on reference data from a relevant population (the cutoff value is not well-defined, and could be $10^{\text {th }}, 5^{\text {th }}$ percentile or at least-2SD from the mean).

Based on the difficulty of getting a worldwide cutoff value, the consensus statement recommends the use of weight and/or length below -2SD (14), because with this definition, those at risk of short stature are well- -identified. The cutoff value used for neonatologists and obstetricians remains the weight below the $10^{\text {th }}$ percentile because it identifies those at risk of perinatal morbimortality.

Being born SGA is not a synonym of being born with low birthweight or intrauterine growth retardation (17). Usually, the term LBW is used for those born weighting less than $2500 \mathrm{~g}$, independent of their gestational age. Conversely, intrauterine growth restriction requires the description of at least two intrauterine ultrasound measurements showing decline in weight percentile.

On the other hand, metabolic syndrome has not a universally accepted definition. Most of these definitions were adaptations from the adult criteria developed by the National Cholesterol Education Program (18). The International Diabetes Federation and American Heart Association have both recently proposed a revised definition of MS in children and adolescents (19) which includes waist circumference $\geq 90^{\text {th }}$ percentile for age, sex and race, higher levels of blood pressure, triglycerides and fasting glucose and low levels of HDL-cholesterol (Table 1).

\section{Epigenetic link between birth size and metaboli}

Since Barker and Hales proposed the hypothesis of the "thrifty phenotype" in 1992, much has been written about the relationship between the implications of nutritional status during fetal and early postnatal life, and the permanent programming of metabolic response in childhood and adult life $(13,20)$. The association is not related to adult environmental confounding factors, such a smoke or inactivity (21). Barker and Hales proposed the existence of an epidemiological association between poor intrauterine nutrition and the development of insulin resistance, impaired glucose tolerance

Table 1. Components of metabolic syndrome

\begin{tabular}{llll}
\hline \multirow{2}{*}{ Age (years) } & IDF Criteria & AHA Criteria \\
\cline { 2 - 4 } & $\mathbf{6 - 9}$ & $\mathbf{1 0 - 1 5}$ & $\mathbf{1 2 - 1 9}$ \\
\hline Waist circumference & $\geq 90^{\text {th }}$ percentile for age & $\geq 90^{\text {th }}$ percentile for age & $\geq 90^{\text {th }}$ percentile for age, sex and race \\
Blood pressure & & Systolic $>130$ or diastolic $>85 \mathrm{mmHg}$ & $\geq 90^{\text {th }}$ percentile for age, sex and height \\
Triglycerides & & $\geq 150 \mathrm{mg} / \mathrm{dL}$ & $\geq 110 \mathrm{mg} / \mathrm{dL}$ \\
HDL-C & & $<40 \mathrm{mg} / \mathrm{dL}$ & $\leq 10^{\text {th }}$ percentile for race and sex \\
Fasting glucose & $\geq 100 \mathrm{mg} / \mathrm{dL}$ & $\geq 100 \mathrm{mg} / \mathrm{dL}$ \\
\hline
\end{tabular}

IDF: International Diabetes Federation; AHA: American Hearth Association; HDL-C: High Density Lipoprotein Cholesterol. For IDF: 3 or more criteria must be present for the diagnosis of metabolic syndrome. For AHA: central obesity and 2 criteria or more. 
and metabolic syndrome in adulthood. Postnatal decrease in insulin sensitivity may result from fetal adaptation to an adverse intrauterine environment during a critical period, leading to programming of fetal gene expression $(13,18)$. Currently, it is well-known that not only those subjects born with low birth weight, but also poor maternal nutrition, increased maternal weight gain $(22,23)$ and large-for-gestational age newborns have increased metabolic risks (24), which means that this association is U-shaped (25).

Not only epidemiological studies in human support the importance of epigenetic changes in mediating the adult phenotype, but also animal studies show that early undernutrition has a permanent effect on the subsequent growth of rats (26). In pregnant rats, reduction in protein intake during pregnancy induces permanent changes in offspring gene expression, such as PPAR- $\alpha$ increased expression in the liver, while others similar enzymes (11-hydroxysteroid dehydrogenase type II) show decreased activity (27). According to current knowledge, epigenetic mechanisms, including DNA methylation, changes in histone structure, and small non-coding RNA activity, provide the molecular basis to developmental plasticity (28).

\section{Metabolic consequences of being born SGA}

\section{Insulin sensitivity and resistance}

Insulin plays a central role in fetal growth. During the first two years of life, especially during the first 12 months of life, SGA newborns are usually able to catch-up growth by increasing their growth velocity above the $50^{\text {th }}$ percentile, and are found nearby their AGA counterparts (29). This trend not only improves the final height, but also has been associated with changes in insulin sensitivity $(11,30)$.

Insulin resistance may be present as early as 1 year of age. In a cohort of 85 SGA and 23 AGA 1-year-olds, stratified according to catch-up growth, SGA with catch-up growth in weight had higher fasting insulin levels, whereas catch-up growth in length had a tendency to higher basal and stimulated insulin levels, suggesting that pathophysiological mechanisms linking prenatal growth and postnatal sensitivity are present early in life (31). The homeostatic model assessment was used to evaluate insulin resistance and insulin secretion in children 1 to 3 years old in a cohort of 50 SGA and 14 AGA newborns and their relationship with
IGF-1 levels. Our group showed that IGF-1 levels were related to beta-cell function and longitudinal growth during the first year of life. By 3 years of age, IGF-I levels were related to body mass index and IR (32). In a study of 477 eight-year-old Indian children, both low birthweight and high fat mass at 8 years old were associated with insulin resistance, higher LDL-cholesterol levels, and higher fasting plasma insulin levels (11). Ibáñez and cols. described that this early growth was associated with development of central adiposity and insulin resistance between 2 to 4 years of age in SGA newborns. They demonstrated SGA children gained more abdominal fat and body adiposity, and less lean mass than AGA children (33). Similarly, in the large ALSPAC cohort, lower birth weight and higher catch-up growth at 3 years old predicted high BMI, high waist circumference and lower insulin sensitivity by 8 years old (34). A large sample from a Netherland cohort, including subjects born SGA, evidenced that the key period of rapid weight gain occurred during the first 3 months of life and was associated with higher percentage of body fat, more central adiposity, and reduced insulin sensitivity in early adulthood (35).

At a later stage of development, our group compared leptin levels, body composition, insulin sensitivity and secretion by the oral glucose tolerance test in healthy, non-obese early pubertal girls, born either AGA or SGA, selected from the general population. We found that at this age, SGA girls had higher levels of leptin and underlying subtle degree of insulin resistance, despite similar BMI (36).

A Danish cohort of children born at term was analyzed at $\mathbf{1 7 . 6}$ years. Rapid weight gain was evidenced from birth to three months of age, and at 1 year old, it predicted higher HOMA-IR and basal insulin levels at 17.6 years old. Accelerated weight gain in AGA does not seem as detrimental in glucose metabolism as in SGA newborns (37). In a French cohort of healthy subjects assessed at 20 years old, insulin and proinsulin concentration were higher in SGA compared with AGA newborns, after being adjusted by BMI and sex, representing an early marker of insulin impairment (38).

The evidence presented before should also be considered in premature babies, even if their catch-up weight growth is slow (39). However, controversy remains as to whether those subjects born premature and SGA have a worse metabolic profile than those born premature but AGA (40). 


\section{Glucose intolerance and type 2 diabetes}

Insulin resistance is considered a risk factor for type 2 diabetes and could represent the prelude of other metabolic manifestations. It is well-known that insulin and glucose metabolism impairment are strictly linked to cardiovascular damage. The proposed hypothesis points out that the interaction leads to dynamic changes in adiposity, because not only quantitative, but also qualitative abnormalities of adipose tissue have been observed in SGA, suggesting a critical role of this organ in the development of metabolic complications. Hales and cols. reported, in 1991, a six-fold increase in risk of developing diabetes in newborns weighing less than $2.5 \mathrm{~kg}$ at birth (1).

Results from the Auckland birthweight collaborative study that determined underlying causes of being born SGA, studied 54 single nucleotide polymorphisms (SNPs) associated with obesity and/or type 2 diabetes, and demonstrated that a genetic variation in KCNJll, BDNF, PFKP, PTER and SEC16B were associated with babies born SGA, supporting the concept that genetic factors associated with obesity and/or type 2 diabetes are more prevalent in those born SGA than in those born AGA (41). Recently, Freathy and cols. described that two alleles (CDKALl and HHEX-IDE) related to the risk of type 2 diabetes were also associated with reduced birthweight. However, the effect was weak (42).

Furthermore, in a group of subjects born SGA cortisol bioactivity correlated positively with HOMA-IR and negatively with adiponectin, suggesting a possible mechanism between SGA and insulin resistance and type 2 diabetes.

Poor insulin secretory ability requires Beta cell impairment, but available studies in humans are not conclusive regarding the association between SGA and beta cell dysfunction (43). Veening and cols. compared Glucose tolerance, insulin sensitivity, and insulin secretion, at 9 years old, in 29 SGA and 24 AGA newborns. They did not find differences in glucose tolerance and Beta cell function between SGA and AGA children at this age. However, those born SGA had a reduction in Insulin sensitivity assessed by the hyperinsulinemic clamp. The authors concluded that SGA may contribute to enhance the risk of developing noninsulin-dependent diabetes mellitus in adult life, especially SGA children with catch-up growth and a high BMI (29).

IGF-1 is a major regulator of growth in stature during childhood. Lower IGF-1 levels in adults have been associated with increased risk of developing Type 2 dia- betes mellitus (44). Román and cols., in our group, studied insulin sensitivity using the oral glucose tolerance test and IGF-I sensitivity, determining nocturnal GH concentrations at baseline and after administration of recombinant human IGF-I/IGFBP-3 complex. LBW children in the lowest quartile of insulin sensitivity exhibited lower pituitary GH response to the administration of rhIGF-I/rhIGFBP-3. The authors concluded that reduced sensitivity to insulin and IGF-I may coexist in some prepubertal LBW children (45).

Reports comparing short SGA subjects treated or not with growth hormone demonstrated that fasting glucose and insulin levels increased during GH treatment, but recovered after discontinuation, suggesting long term GH treatment did not increase the risk of type 2 diabetes mellitus in SGA $(46,47)$.

\section{Cardiovascular disease}

Programming of adaptive responses in children born SGA includes an association with increased blood pressure, changes in endothelial function, arterial properties and coronary disease (48-50).

A systematic review of the literature assessing blood pressure and involving more than 66,000 subjects aged 0-71 years old have found 34 studies describing an inverse relationship between blood pressure and birthweight in children and adults. Surprisingly, these findings were not replicated in an adolescent group (47). Bilge and cols. investigated the relationship between birthweight and blood pressure (monitoring ambulatory blood pressure), at 8 years old, in 39 children born SGA compared with 27 children born AGA. They did not find differences between the groups at this age (51). Differences in systolic pressure for every $1-\mathrm{kg}$ difference in birthweight were estimated to be $2-4 \mathrm{mmHg}$.

The possible mechanisms involved in the development of high blood pressure include a reduction in the number of nephrons; changes in renin-angiotensinaldosterone system and increased mineralocorticoid activity due to changes in type $211 \beta$-hydroxysteroid dehydrogenase, which inactivates cortisol; and endothelium modifications (52).

Bradley and cols. assessed the biophysical properties of the aorta in 39 SGA and 41 AGA children, at the ages 8 to 13 years. The echo-Doppler results demonstrated abnormal biophysical properties of the aorta in patients born SGA who remained short and continued to have normal blood pressure (53). Carotid and bra- 
chial arterial measurements using ultrasound and flow-mediated dilation evidenced that children born SGA had endothelial dysfunction with normal intima-media thickness (46).

Barker described, in 1995, the relationship between cardiovascular disease and fetal environment, since much has been published about this association to that date (54). A follow-up of 5,654 men born from 1911 to 1930 in England demonstrated that men with the lowest weights at birth at one year of age had highest death rates from ischemic heart disease (55). The same results have been replicated in studies in South India and Finland $(56,57)$.

\section{Metabolic syndrome}

For several years, the epidemiological data have shown different components of metabolic syndrome during life in babies born SGA. Several associations between birthweight and the separate components of the syndrome have been found. The dynamic changes in adiposity that occur during this period suggest a critical role in the development of metabolic complications. Metabolic disorders in SGA individuals are amplified by weight gain with time when adults, both probably influenced by fetal programming (58).

Meas and cols. reported a two fold higher risk of developing metabolic syndrome over the 8 year follow-up of SGAs, after adjustment for gain in BMI (59). In the cohort of Haguenau, in France, the incidence by age 22 was $2.4 \%$ in those born SGA compared with $0.4 \%$ in those born AGA. In an urban Chinese cohort of 2,019 subjects born between 1921 and 1954, those who had lower birthweight and higher age, body mass index, and waist circumference at follow-up presented with all the five components of metabolic syndrome. Subjects who had birthweights of less than 2,500 g were $66 \%$ more likely to develop a greater number of metabolic syndrome components in adulthood (60).

Some of the components of metabolic syndrome could be present as early as prepubertal age. Therefore, strategies intended to prevent the development of metabolic syndrome should be addressed early.

\section{PREVENTION}

Since the first observation made by Barker and Hales linking size at birth and early postnatal development of chronic non-transmissible diseases, many authors have been interested and explored these associations. Public health policies should be deal with the potential risk that children born SGA have in their adulthood. Strategies designated to prevent fast weight gain during early infancy and prepubertal age and to promote a healthy life style are mandatory (61).

Promotion of fast weight gain in SGA infants by nutrient-enriched formula feeding should be used with caution. However, growth limitation by restriction of nutrition in SGA infants below general recommendations should not be suggested. Indeed, changes in Ghrelin dynamics, an orexigenic hormone have been implicated in the well-known differences in appetite in children born SGA (62). Whether these differences are present in those born LGA, implications in postnatal weight gain is unknown.

In conclusion, subjects born SGA are at high risk of developing chronic diseases, including insulin resistance, obesity, type 2 diabetes and cardiovascular disease, all of them part of the metabolic syndrome. It is well-known that not only low weight and/or size at birth increase the risk, but also rapid gain weight during the first years of life contribute to the development of chronic diseases since early life.

Strategies designated to prevent high weight gain in pregnant women and to promote appropriate nutrition during pregnancy, preventing fast weight gain during early infancy and prepubertal age, and that promote a healthy life style are the keys to decrease the risk.

Disclosure: no potential conflict of interest relevant to this article was reported.

\section{REFERENCES}

1. Hales CN, Barker DJ, Clark PM, Cox LJ, Fall C, Osmond C, et al. Fetal and infant growth and impaired glucose tolerance at age 64 . BMJ. 1991;303:1019-22.

2. Barker DJ, Hales CN, Fall CH, Osmond C, Phipps K, Clark PM. Type 2 (non-insulin-dependent) diabetes mellitus, hypertension and hyperlipidaemia (syndrome $\mathrm{X}$ ): relation to reduced fetal growth. Diabetologia. 1993;36:62-7.

3. Salonen MK, Kajantie E, Osmond C, Forsén T, Ylihärsilä $H$, et al Childhood growth and future risk of the metabolic syndrome in normal-weight men and women. Diabetes Metab. 2009;35:143-50.

4. Barker DJ. The fetal origins of adult hypertension. J Hypertens Suppl. 1992;10:S39-44.

5. Barker DJ, Martyn CN. The maternal and fetal origins of cardiovascular disease. J Epidemiol Community Health. 1992;46:8-11.

6. Barker DJ, Osmond C, Golding J, Kuh D, Wadsworth ME. Growth in utero, blood pressure in childhood and adult life, and mortality from cardiovascular disease. BMJ. 1989;298:564-7.

7. Barker DJ, Winter PD, Osmond C, Margetts B, Simmonds SJ. Weight in infancy and death from ischaemic heart disease. Lancet. 1989;2:577-80.

8. Phillips DI, Barker DJ, Fall CH, Seckl JR, Whorwood CB, et al. Elevated plasma cortisol concentrations: a link between low birth 
weight and the insulin resistance syndrome? J Clin Endocrinol Metab. 1998;83:757-60.

9. Ibáñez L, Potau N, Francois I, de Zegher F. Precocious pubarche, hyperinsulinism, and ovarian hyperandrogenism in girls: relation to reduced fetal growth. J Clin Endocrinol Metab. 1998;83:3558-62.

10. Ibáñez L, Potau N, Marcos MV, de Zegher F. Exaggerated adrenarche and hyperinsulinism in adolescent girls born small for gestational age. J Clin Endocrinol Metab. 1999;84:4739-41.

11. Bavdekar A, Yajnik CS, Fall CH, Bapat S, Pandit AN, Deshpande V, et al. Insulin resistance syndrome in 8-year-old Indian children: small at birth, big at 8 years, or both? Diabetes. 1999;48:2422-9.

12. Hofman PL, Cutfield WS, Robinson EM, Bergman RN, Menon RK, Sperling MA, et al. Insulin resistance in short children with intrauterine growth retardation. J Clin Endocrinol Metab. 1997;82:402-6.

13. Mericq V, Ong KK, Bazaes R, Peña V, Avila A, SalazarT, et al. Longitudinal changes in insulin sensitivity and secretion from birth to age three years in small- and appropriate-for-gestational-age children. Diabetologia. 2005;48:2609-14.

14. Hales CN, Barker DJ. The thrifty phenotype hypothesis. Br Med Bull. 2001;60:5-20.

15. Ay L, Van Houten VA, Steegers EA, Hofman A, Witteman JC, et al. Fetal and postnatal growth and body composition at 6 months of age. J Clin Endocrinol Metab. 2009;94:2023-30.

16. Clayton PE, Cianfarani S, Czernichow P, Johannsson G, Rapaport $R$, Rogol A. Management of the child born small for gestational age through to adulthood: a consensus statement of the International Societies of Pediatric Endocrinology and the Growth Hormone Research Society. J Clin Endocrinol Metab. 2007;92:804-10.

17. Chatelain $P$. Children born with intra-uterine growth retardation (IUGR) or small for gestational age (SGA): long term growth and metabolic consequences. Endocr Regul. 2000;34:33-6.

18. Ford ES, Li C. Defining the metabolic syndrome in children and adolescents: will the real definition please stand up? J Pediatr. 2008;152:160-4.

19. Zimmet P, Alberti KG, Kaufman F, Tajima N, Silink M, et al.; IDF Consensus Group. The metabolic syndrome in children and adolescents - an IDF consensus report. Pediatr Diabetes. 2007;8:299-306.

20. Hales CN, Barker DJ. Type 2 (non-insulin-dependent) diabetes mellitus: the thrifty phenotype hypothesis. Diabetologia. 1992;35:595-601.

21. Godfrey KM. The "Developmental Origins" hypothesis: epidemiology. In: Gluckman PD, Hanson MA (eds.). Developmental origins of health and disease-A biomedical perspective. Cambridge University Press; 2006. p. 6-32.

22. Fraser A, Tilling K, Macdonald-Wallis C, Sattar N, Brion MJ, Benfield $L$, et al. Association of maternal weight gain in pregnancy with offspring obesity and metabolic and vascular traits in childhood. Circulation. 2010;121:2557-64.

23. Reynolds RM, Osmond C, Phillips DI, Godfrey KM. Maternal BMI, parity, and pregnancy weight gain: influences on offspring adiposity in young adulthood. J Clin Endocrinol Metab. 2010;95:5365-9.

24. Dyer JS, Rosenfeld CR, Rice J, Rice M, Hardin DS. Insulin resistance in Hispanic large-for-gestational-age neonates at birth. $\mathrm{J}$ Clin Endocrinol Metab. 2007;92:3836-43.

25. Dabelea D, Pettitt DJ, Hanson RL, Imperatore G, Bennett PH, Knowler WC. Birth weight, type 2 diabetes, and insulin resistance in Pima Indian children and young adults. Diabetes Care. 1999;22:944-50.

26. McCance RA, Widdowson EM. Protein deficiencies and calorie deficiencies. Lancet. 1966;2:158-9.

27. Godfrey KM, Lillycrop KA, Burdge GC, Gluckman PD, Hanson MA. Epigenetic mechanisms and the mismatch concept of the developmental origins of health and disease. Pediatr Res. 2007;61(5 Pt 2):5R-10R.
28. Gluckman PD, Hanson MA, Buklijas T, Low FM, Beedle AS. Epigenetic mechanisms that underpin metabolic and cardiovascular diseases. Nat Rev Endocrinol. 2009;5:401-8.

29. Boersma B, Wit JM. Catch-up growth. Endocr Rev. 1997;18:646-61.

30. Veening MA, Van Weissenbruch MM, Delemarre-Van De Waal HA. Glucose tolerance, insulin sensitivity, and insulin secretion in children born small for gestational age. J Clin Endocrinol Metab. 2002;87:4657-61.

31. Soto $N$, Bazaes RA, Peña $V$, Salazar T, Avila A, Iñiguez $G$, et al. Insulin sensitivity and secretion are related to catch-up growth in small-for-gestational-age infants at age 1 year: results from a prospective cohort. J Clin Endocrinol Metab. 2003;88:3645-50.

32. Iñiguez $G$, Ong $K$, Bazaes $R$, Avila $A$, Salazar T, et al. Longitudinal changes in insulin-like growth factor-l, insulin sensitivity, and secretion from birth to age three years in small-for-gestational-age children. J Clin Endocrinol Metab. 2006;91:4645-9.

33. Ibáñez L, Ong K, Dunger DB, de Zegher F. Early development of adiposity and insulin resistance after catch-up weight gain in small-for-gestational-age children. J Clin Endocrinol Metab. 2006;91:2153-8.

34. Ong KK, Petry CJ, Emmett PM, Sandhu MS, Kiess W, et al.; ALSPAC study team. Insulin sensitivity and secretion in normal children related to size at birth, postnatal growth, and plasma insulin-like growth factor-I levels. Diabetologia. 2004;47:1064-70.

35. Leunissen RW, Kerkhof GF, Stijnen T, Hokken-Koelega A. Timing and tempo of first-year rapid growth in relation to cardiovascular and metabolic risk profile in early adulthood. JAMA. 2009;301:2234-42.

36. Martínez-Aguayo A, Capurro T, Peña V, Iñiguez G, Hernández MI, et al. Comparison of leptin levels, body composition and insulin sensitivity and secretion by OGTT in healthy, early pubertal girls born at either appropriate- or small-for-gestational age. Clin Endocrinol (Oxf). 2007;67:526-32.

37. Fabricius-Bjerre $\mathrm{S}$, Jensen RB, Færch $\mathrm{K}$, Larsen T, Mølgaard C, Fleischer K, et al. Impact of birthweight and early infant weight gain on insulin resistance and associated cardiovascular risk factors in adolescence. PLoS One. 2011;6:e20595.

38. Leger J, Levy-Marchal C, Bloch J, Pinet A, Chevenne D, Porquet D, et al. Reduced final height and indications for insulin resistance in 20 year olds born small for gestational age: regional cohort study. BMJ. 1997;315:341-7.

39. Bazaes RA, Mericq V. Premature birth and insulin resistance. N Engl J Med. 2005;352:939-40.

40. Bazaes RA, Alegría A, Pittaluga E, Avila A, Iñiguez G, Mericq V. Determinants of insulin sensitivity and secretion in very-low-birth-weight children. J Clin Endocrinol Metab. 2004;89:1267-72.

41. Morgan AR, Thompson JM, Murphy R, Black PN, Lam WJ, et al. Obesity and diabetes genes are associated with being born small for gestational age: results from the Auckland Birthweight Collaborative study. BMC Med Genet. 2010;11:125.

42. Freathy RM, Bennett AJ, Ring SM, Shields B, Groves CJ,Timpson $\mathrm{NJ}$, et al. Type 2 diabetes risk alleles are associated with reduced size at birth. Diabetes. 2009;58:1428-33.

43. Beringue F, Blondeau B, Castellotti MC, Breant B, Czernichow P, Polak M. Endocrine pancreas development in growth-retarded human fetuses Diabetes. 2002;51:385-91.

44. Sandhu MS, Heald AH, Gibson JM, et al. Circulating concentrations of insulin-like growth factor-I and development of glucose intolerance: a prospective observational study. Lancet. 2002;359:1740-5.

45. Román R, Iñiguez G, SalazarT, Avila A, Barrera A, Mericq V, et al. Relationship between insulin sensitivity and IGF-I sensitivity in low birth weight prepubertal children. Horm Res. 2008;70:73-8.

46. van Dijk M, Bannink EM, van Pareren YK, Mulder PG, Hokken-Koelega AC. Risk factors for diabetes mellitus type 2 and metabolic 
syndrome are comparable for previously growth hormone-treated young adults born small for gestational age (sga) and untreated short SGA controls. J Clin Endocrinol Metab. 2007;92:160-5.

47. Hokken-Koelega AC, van Pareren Y, Sas T, Arends N. Final height data, body composition and glucose metabolism in growth hormone-treated short children born small for gestational age. Horm Res. 2003;60Suppl 3:113-4.

48. Meas T. Fetal origins of insulin resistance and the metabolic syndrome: a keyrole for adipose tissue? Diabetes Metab. 2010;36:11-20.

49. Jouret B, Dulac $Y$, Bassil Eter R, Taktak A, Cristini C, Lounis N, et al. Endothelial function and mechanical arterial properties in children born small for gestational age: comparison with obese children. Horm Res Paediatr. 2011;76(4):240-7.

50. Law CM, Shiell AW. Is blood pressure inversely related to birth weight? The strength of evidence from a systematic review of the literature. J Hypertens. 1996;14:935-41.

51. Bilge I, Poyrazoglu S, Bas F, Emre S, Sirin A, Gokalp S, et al. Ambulatory blood pressure monitoring and renal functions in term small-for-gestational age children. Pediatr Nephrol. 2011;26:119-26.

52. Dötsch J. Renal and extrarenal mechanisms of perinatal programming after intrauterine growth restriction. Hypertens Res.

53. 2009;32:238-41.

54. Bradley TJ, Potts JE, Lee SK, Potts MT, De Souza AM, Sandor GG. Early changes in the biophysical properties of the aorta in pre-adolescent children born small for gestational age. J Pediatr. 2010;156:388-92.

55. Barker DJ. Fetal origins of coronary heart disease. BMJ. 1995;311:171-4.
56. Barker DJ, Winter PD, Osmond C, Margetts B, Simmonds SJ. Weight in infancy and death from ischaemic heart disease. Lancet. 1989;2:577-80.

57. Stein $\mathrm{CE}$, Fall $\mathrm{CH}$, Kumaran $\mathrm{K}$, Osmond $\mathrm{C}$, Cox V, Barker DJ. Fetal growth and coronary heart disease in south India. Lancet. 1996;348:1269-73.

58. Forsen T, Eriksson JG, Tuomilehto J, Teramo K, Osmond C, Barker DJ. Mother's weight in pregnancy and coronary heart disease in a cohort of Finnish men: follow-up study. BMJ. 1997;315:837-40.

59. Levy-Marchal C, Arslanian S, Cutfield W, Sinaiko A, Druet C, Marcovecchio ML, et al.; ESPE-LWPES-ISPAD-APPES-APEG-SLEP-JS$P E ;$ Insulin Resistance in Children Consensus Conference Group. Insulin resistance in children: consensus, perspective, and future directions. J Clin Endocrinol Metab. 2010;95:5189-98.

60. Meas T, Deghmoun S, Alberti C, Carreira E, Armoogum P, Chevenne $D$, et al. Independent effects of weight gain and fetal programming on metabolic complications in adults born small for gestational age. Diabetologia. 2010;53:907-13.

61. Xiao X, Zhang ZX, Li WH, Feng K, Sun Q, Cohen HJ, et al. Low birth weight is associated with components of the metabolic syndrome. Metabolism. 2010;59:1282-6.

62. Wojcicki JM, Heyman MB. Let's move--childhood obesity prevention from pregnancy and infancy onward. $N$ Engl $J$ Med. 2010;362:1457-9.

63. Iñiguez G, Ong K, Peña V, Avila A, Dunger D, Mericq V. Fasting and post-glucose ghrelin levels in SGA infants: relationships with size and weight gain at one year of age. J Clin Endocrinol Metab. 2002;87:5830-3. 